\title{
Gambogic acid reverses oxaliplatin resistance in colorectal cancer by increasing intracellular platinum levels
}

\author{
QIANG WANG $^{1 *}$, JIANCHANG WEI $^{1 *}$, CHENGXING WANG $^{1,2 *}$, TONG ZHANG ${ }^{1}$, DI HUANG ${ }^{1}$, FANG WEI $^{1}$, \\ FENG HE ${ }^{1}$, WENSONG CAI ${ }^{1}$, PING YANG ${ }^{1}$, SHANQI ZENG ${ }^{1}$, WANGLIN LI ${ }^{1}$ and JIE CAO ${ }^{1}$ \\ ${ }^{1}$ Department of General Surgery, Guangzhou Digestive Disease Centre, Guangzhou First People's Hospital, \\ Guangzhou Medical University, Guangzhou, Guangdong 510180; ${ }^{2}$ Department of Gastrointestinal Surgery, \\ Jiangmen Central Hospital, Affiliated Jiangmen Hospital of Sun Yat-sen University, Jiangmen, Guangdong 529000, P.R. China
}

Received October 18, 2017; Accepted April 5, 2018

DOI: $10.3892 / 01.2018 .8916$

\begin{abstract}
Resistance to oxaliplatin (L-OHP) is a major obstacle to successful chemotherapy in colorectal cancer (CRC). In the present study, the ability of gambogic acid (GA) to reverse L-OHP resistance in CRC LoVo cells was investigated. L-OHP-resistant $\mathrm{LoVo} / \mathrm{L}-\mathrm{OHP}$ cells were established by exposing them to increasing concentrations of L-OHP. GA-reversed L-OHP-sensitive LoVo/L-OHP/GA cells were established by exposure to $0.5 \mu \mathrm{mol} / 1 \mathrm{GA}$ for 2 weeks. A Cell Counting Kit-8 assay was used to assess levels of proliferation. Flow cytometry was applied to detect apoptosis rates. Transwell assays were used to analyse invasion. Inductively coupled plasma mass spectrometry was used to determine intracellular platinum (Pt) content. Western blot analysis was used to reveal the protein levels of Human copper transporter 1 (hCTR1), Copper-transporting p-type adenosine triphosphatases 1 (ATP7A) and Copper-transporting p-type adenosine triphosphatases 2 (ATP7B). LoVo/L-OHP and LoVo/L-OHP/GA cell lines were successfully established, and it was identified that L-OHP inhibited the proliferation of LoVo, LoVo/L-OHP and $\mathrm{LoVo} / \mathrm{L}-\mathrm{OHP} / \mathrm{GA}$ cells in a dose-dependent manner. Compared with the parent LoVo cells, the anti-apoptosis and invasion properties of LoVo/L-OHP cells were enhanced, and were reversed by GA treatment. Intracellular Pt content was highest in the LoVo cells, followed by LoVo/L-OHP/GA cells,
\end{abstract}

Correspondence to: Dr Jie Cao, Department of General Surgery, Guangzhou Digestive Disease Centre, Guangzhou First People's Hospital, Guangzhou Medical University, 1 Panfu Road, Guangzhou, Guangdong 510180, P.R. China

E-mail: czhongt@126.com

${ }^{*}$ Contributed equally

Abbreviations: GA, gambogic acid; L-OHP, oxaliplatin; CRC, colorectal cancer; Pt, platinum; hCTR1, human copper transporter 1; ATP7A, copper-transporting p-type adenosine triphosphatases 1; ATP7B, copper-transporting p-type adenosine triphosphatases 2

Key words: gambogic acid, oxaliplatin, resistance, colorectal cancer and then lowest in the LoVo/L-OHP cells. Downregulated hCTP1 and upregulated ATP7A and ATP7B were associated with L-OHP resistance, and GA reversed the resistance by increasing levels of hCTR1 and decreasing levels of ATP7A and ATP7B. In conclusion, GA has the potential ability to reverse L-OHP resistance in CRC cells by increasing intracellular Pt content, which it achieves by increasing hCTR1 levels and decreasing ATP7A and ATP7B levels. GA may represent a promising treatment agent for L-OHP resistance.

\section{Introduction}

Colorectal cancer (CRC), the second-most diagnosed cancer and the fourth-most frequent cause of cancer-associated mortality (1), remains one of the most serious health problems worldwide. In China, it ranks fifth in the morbidity and mortality rates among all types of cancer, with 191,000 mortalities in 2015 (2).

Chemotherapy serves a vital role in the treatments of CRC, particularly for patients with advanced CRC; it lessens the number and severity of clinical symptoms, improves the quality of lives and prolongs survival (3). Drug resistance is a major obstacle in chemotherapy (4). Oxaliplatin (L-OHP), a third-generation platinum $(\mathrm{Pt})$ compound, is the first-line drug for CRC chemotherapy (5). However, resistance to L-OHP leads to treatment failure and relapse in patients with CRC (4).

Reduced intracellular Pt accumulation has been identified as a major mechanism of L-OHP resistance (6). Adequate accumulation of intracellular $\mathrm{Pt}$ is essential for anticancer drugs to exert their cytotoxic effects (7). Copper transporters serve important roles in the cellular import and export of Pt drugs (8). Human copper transporter 1 (hCTR1) and Copper-transporting p-type adenosine triphosphatases 1 (ATP7A) and 2 (ATP7B) have been identified as key copper transporters (9). hCTR1 regulates the influx of Pt drugs, while ATP7A and ATP7B regulate their efflux (9). The upregulation of hCTR1 and downregulation of ATP7A and ATP7B may be potential mechanisms of L-OHP resistance (10).

Gambogic acid (GA), an active component of the traditional Chinese medicine Garcinia hanburyi, exhibits multi-target anti-tumour effects with few side effects (11). Previously, GA was identified to be able to reverse resistance 
to anticancer drugs, including resistance to 5-fluorouracil in CRC (12), to doxorubicin in breast (13) and ovarian cancer (14), and to docetaxel in gastric (15) and human epithelial cancer (16).

However, to the best of our knowledge, the ability of GA to reverse L-OHP resistance in CRC cells has not been investigated. Therefore, in the present study, using a step-wise increasing concentration method, L-OHP-resistant LoVo/ L-OHP and L-OHP-sensitive LoVo/L-OHP/GA cell lines were successfully established, and it was identified that GA may reverse L-OHP resistance, potentially by increasing intracellular platinum through increasing hCTP1 and decreasing ATP7A and ATP7B protein levels. GA may represent a promising treatment agent for L-OHP resistance.

\section{Materials and methods}

Materials. LoVo cells were obtained from the American Type Culture Collection (Manassas, VA, USA) and were cultured in RPMI-1640 medium (Gibco; Thermo Fisher Scientific, Inc., Waltham, MA, USA) with $10 \%$ foetal bovine serum (FBS; Thermo Fisher Scientific, Inc.) at $37^{\circ} \mathrm{C}$ with $5 \% \mathrm{CO}_{2}$. L-OHP was purchased from Jiangsu Hengrui Pharmaceutical Co., Ltd. (cat no. H20000337; Lianyungang, China). GA was purchased from Sigma-Aldrich; Merck KGaA (Darmstadt, Germany). The Cell Counting Kit-8 (CCK-8) was obtained from Beyotime Institute of Biotechnology (Haimen, China). The Alexa Fluor ${ }^{\circledR} 488$ Annexin V/Dead Cell Apoptosis kit was purchased from Invitrogen; Thermo Fisher Scientific, Inc. Antibodies against hCTR1 (cat. no. ab108481; rabbit polyclonal), ATP7A (cat. no. ab42486; rabbit polyclonal), ATP7B (cat. no. ab124973; rabbit monoclonal) and GAPDH (cat. no. ab9485; rabbit polyclonal) were purchased from Abcam (Cambridge, MA, USA).

Establishment of LoVo/L-OHP and LoVo/L-OHP/GA cell lines. The L-OHP-resistant LoVo/L-OHP cell line was established by exposing LoVo cells to increasing concentrations of L-OHP (1, 2, 4, 6, 8, 10, 12, 14, 16, 18, 20, 25, 30, 35, 40, 45 and $50 \mu \mathrm{mol} / \mathrm{l})$ for $48 \mathrm{~h}$ at each concentration as described previously $(17,18)$. LoVo/L-OHP cells were then cultured in complete RPMI-1640 medium with $4 \mu \mathrm{mol} / 1 \mathrm{~L}-\mathrm{OHP}$ at $37^{\circ} \mathrm{C}$ with $5 \% \mathrm{CO}_{2}$. After 6 months, LoVo/L-OHP cells capable of growing in $60 \mu \mathrm{mol} / 1 \mathrm{~L}-\mathrm{OHP}$ were obtained. To examine the effects of drug intervention, the culture medium was changed to complete RPMI-1640 medium without L-OHP 1 week prior to experimentation.

The GA-reversed L-OHP-sensitive LoVo/L-OHP/GA cell line was established by continuous exposure of LoVo/L-OHP cells to GA.

Briefly, LoVo/L-OHP cells were cultured in complete RPMI-1640 medium without L-OHP for 1 week, and then cultured in complete RPMI-1640 medium with $0.5 \mu \mathrm{mol} / 1 \mathrm{GA}$ at $37^{\circ} \mathrm{C}$ with $5 \% \mathrm{CO}_{2}$ for 2 weeks. The culture medium was changed every $24 \mathrm{~h}$. The LoVo/L-OHP/GA cells were then collected and stored for subsequent experiments.

Morphological observations. The recovery established LoVo, $\mathrm{LoVo} / \mathrm{L}-\mathrm{OHP}$ or $\mathrm{LoVo} / \mathrm{L}-\mathrm{OHP} / \mathrm{GA}$ cells were cultured to $\sim 80 \%$ confluency. Cells were observed after $24 \mathrm{~h}$ using an inverted light microscope (magnification, x800) in order to observe morphological changes.

Cell viability assay. Cytotoxicity was determined by a CCK-8 assay. Briefly, LoVo, LoVo/L-OHP or LoVo/L-OHP/GA cells $\left(4 \times 10^{4}\right.$ cells $\left./ \mathrm{ml}\right)$ were cultured in 96 -well plates overnight. A total of $100 \mu \mathrm{l}$ of different concentrations of L-OHP $(0,5,10$, $15,20,25,30,35,40,45,50,55$ and $60 \mu \mathrm{mol} / \mathrm{l})$ were then added for at $37^{\circ} \mathrm{C}$ with $5 \% \mathrm{CO}_{2} 48 \mathrm{~h}$. Next, $10 \mu \mathrm{l} \mathrm{CCK-8} \mathrm{reagent} \mathrm{was}$ added for $2 \mathrm{~h}$, and the absorbance at $450 \mathrm{~nm}$ was determined on a microplate reader (iMark ${ }^{\mathrm{TM}}$; Bio-Rad Laboratories, Inc., Hercules, CA, USA). Resistance index (RI)=half maximal inhibitory concentration $\left(\mathrm{IC}_{50}\right)$ of drug-resistant cells/ $/ \mathrm{IC}_{50}$ of drug-sensitive cells (10).

Assessment of cell apoptosis. Cells were harvested $(0.25 \%$ trypsin was added for $30 \mathrm{sec}$ to digest the cells, followed by centrifugation at $560 \mathrm{x} \mathrm{g}$ at $37^{\circ} \mathrm{C}$ for $5 \mathrm{~min}$ and the supernatant was then discarded) following treatment with $20 \mu \mathrm{mol} / 1$ L-OHP for $6 \mathrm{~h}$ and re-suspended in Annexin-binding buffer (Invitrogen; Thermo Fisher Scientific, Inc.) to a concentration of $2 \times 10^{6} / \mathrm{ml}$. Annexin V (solution in $25 \mathrm{mM}$ HEPES, $140 \mathrm{mM}$ $\mathrm{NaCl}, 1 \mathrm{mM}$ EDTA, pH 7.4, 0.1\% bovine serum albumin) and propidium iodide working solutions $(1 \mathrm{mg} / \mathrm{ml})$ were then added at room temperature for $15 \mathrm{~min}$. Flow cytometry (BD Biosciences, Franklin Lakes, NJ, USA) was then performed, and data was analysed using FlowJo 7.6 software (FlowJo LLC, Ashland, OR, USA).

Transwell matrix penetration assay. Cells (LoVo, $\mathrm{LoVo} / \mathrm{L}-\mathrm{OHP}$ and $\mathrm{LoV} / \mathrm{L}-\mathrm{OHP} / \mathrm{GA}$ cells) were cultured in RPMI-1640 medium without FBS for $24 \mathrm{~h}$, following which $2 \times 10^{4} / \mathrm{ml}$ cells suspended in $2 \mu \mathrm{mol} / 1 \mathrm{~L}-\mathrm{OHP}$ were plated in the upper chamber of a polycarbonate Transwell filter in BioCoat ${ }^{\mathrm{TM}}$ Invasion Chambers (BD Biosciences) and incubated for at $37^{\circ} \mathrm{C}$ with $5 \% \mathrm{CO}_{2}$ for $24 \mathrm{~h}$. RPMI-1640 medium with $10 \%$ FBS was added to the lower chamber at $37^{\circ} \mathrm{C}$ with $5 \% \mathrm{CO}_{2}$ for $24 \mathrm{~h}$. Cells that migrated to the lower membrane were fixed with $1 \%$ paraformaldehyde at $37^{\circ} \mathrm{C}$ for $10 \mathrm{~min}$, stained with $1 \%$ haematoxylin at $37^{\circ} \mathrm{C}$ for $10 \mathrm{~min}$ and counted by microscopy in 10 fields of view using a light microscope (magnification, $\mathrm{x} 400$ ).

Intracellular accumulation of Pt. A total of $1 \times 10^{7}$ cells $/ \mathrm{ml}$ of LoVo, LoVo/L-OHP or LoVo/L-OHP/GA cells were seeded into $10 \mathrm{~cm}$ culture dishes for $24 \mathrm{~h}$. Then, $0,0.5,1,2$ or $4 \mu \mathrm{mol} / 1$ L-OHP was added for $4 \mathrm{~h}$, or $2 \mu \mathrm{mol} / 1 \mathrm{~L}-\mathrm{OHP}$ for $1,4,12$ or $24 \mathrm{~h}$. Cells were harvested $(0.25 \%$ trypsin was added for $30 \mathrm{sec}$ to digest the cells, followed by centrifugation at $560 \mathrm{x}$ g at $37^{\circ} \mathrm{C}$ for $5 \mathrm{~min}$ and the supernatant was then discarded) following treatment, washed with PBS and lysed with TRIzol ${ }^{\circledR}$ (Life Technologies; Thermo Fisher Scientific, Inc.). Intracellular Pt was determined by inductively coupled plasma mass spectrometry (ICP-MS; PerkinElmer, Inc., Waltham, MA, USA) as described previously (19).

Western blotting. Total protein from LoVo, LoVo/L-OHP and LoVo/L-OHP/GA cells were extracted with SDS-PAGE Sample loading buffer (cat no. P0015; Beyotime Institute of Biotechnology), and proteins were determined using the 


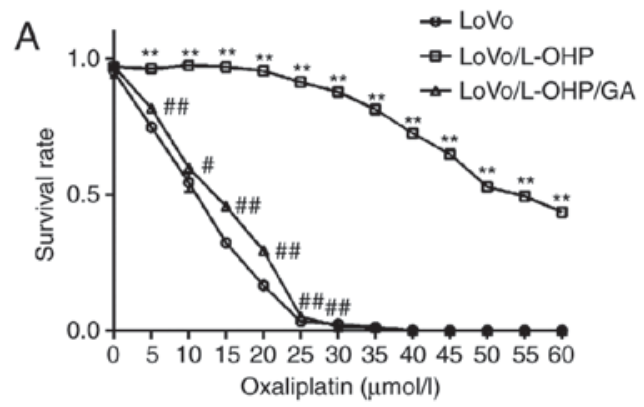

\begin{tabular}{|c|c|c|c|c|c|}
\hline & \multirow{2}{*}{$\frac{\text { LoVo }}{\text { IC50 }}$} & \multicolumn{2}{|c|}{ LoVo/L-OHP } & \multicolumn{2}{|c|}{ LoVo/L-OHP/GA } \\
\hline & & IC50 & RI & IC50 & RI \\
\hline First established & 11.82 & 53.81 & 4.55 & 12.54 & 1.06 \\
\hline $15 \mathrm{~d}$ without L-OHP/GA & 11.82 & 46.43 & 3.92 & 12.93 & 1.09 \\
\hline Recovery cells & 11.82 & 47.97 & 4.05 & 13.92 & 1.18 \\
\hline
\end{tabular}

Figure 1. L-OHP inhibits the proliferation of LoVo, LoVo/L-OHP and LoVo/L-OHP/GA cells. (A) Survival rates of LoVo, LoVo/L-OHP and LoVo/L-OHP/GA cells in the presence of L-OHP. ${ }^{* *} \mathrm{P}<0.01,{ }^{*} \mathrm{P}<0.05$ and ${ }^{\# /} \mathrm{P}<0.01$ vs. LoVo cells. (B) L-OHP IC ${ }_{50}$ of LoVo, LoVo/L-OHP and LoVo/L-OHP/GA cells at different times. L-OHP, oxaliplatin; GA, gambogic acid; $\mathrm{IC}_{50}$, half maximal inhibitory concentration; RI, resistance index; d, days.

Bradford method (14). A total of $50 \mathrm{~g}$ protein was resolved using SDS-PAGE (10\% separating glue and $4 \%$ concentrated glue) and transferred on to polyvinylidene fluoride membranes. Subsequent to blocking with 5\% non-fat milk dissolved in Tris-buffered saline with Tween-20 buffer (Tris-Hcl, $\mathrm{NaCl}$ and Tween-20) at $37^{\circ} \mathrm{C}$ for $1 \mathrm{~h}$, the membranes were incubated with anti-hCTR1 (1:1,000), anti-ATP7A $(1: 1,000)$, anti-ATP7B $(1: 1,000)$ and anti-GAPDH $(1: 1,000)$ antibodies at $4^{\circ} \mathrm{C}$ overnight. The membranes were then incubated with $15 \mathrm{ml}$ horseradish peroxidase-labelled secondary antibody (1:2,000; cat no. 31490; Thermo Fisher Scientific, Inc.) at room temperature for $1 \mathrm{~h}$. Signals were visualised with the SuperSignal West PICO chemiluminescent detection system (Pierce; Thermo Fisher Scientific, Inc.). Image J 1.48 (National Institutes of Health, Bethesda, MD, USA) was used to perform the densitometric analysis.

Statistical analysis. All data were analysed using SPSS 16.0 (SPSS, Inc., Chicago, IL, USA). Values are presented as mean \pm standard deviation. Differences were analysed using one-way analysis of variance followed by a least significant difference post-hoc test. $\mathrm{P}<0.05$ was considered to indicate a statistically significant difference.

\section{Results}

L-OHP inhibits the proliferation of the LoVo, LoVo/L-OHP and LoVo/L-OHP/GA cells. The cytotoxicity of L-OHP to $\mathrm{LoVo}, \mathrm{LoVo} / \mathrm{L}-\mathrm{OHP}$ and $\mathrm{LoV} / \mathrm{L}-\mathrm{OHP} / \mathrm{GA}$ cells was first analysed using a CCK-8 assay. As demonstrated in Fig. 1A, as the concentration of L-OHP increased, the survival rates of cells decreased, indicating that L-OHP increased the levels of cytotoxicity in a dose-dependent manner. The survival rate of the LoVo/L-OHP cells was increased compared with those of the LoVo and LoVo/L-OHP/GA cells $(\mathrm{P}<0.05)$. After $24 \mathrm{~h}$ treatment with $40 \mu \mathrm{mol} / 1 \mathrm{~L}-\mathrm{OHP}$, the LoVo and LoVo/L-OHP/GA cells were almost entirely killed. However, $72.53 \pm 3.06 \% \mathrm{LoVo} / \mathrm{L}-\mathrm{OHP}$ cells survived.

The $\mathrm{IC}_{50}$ of L-OHP was then calculated (Fig. 1B). The L-OHP $\mathrm{IC}_{50}$ for LoVo cells was $11.82 \mu \mathrm{mol} / 1$, while that for the LoVo/L-OHP cells was $53.81 \mu \mathrm{mol} / 1$. The RI for the $\mathrm{LoVo} / \mathrm{L}-\mathrm{OHP}$ cells was 4.55 . The $\mathrm{IC}_{50}$ for the $\mathrm{LoVo} / \mathrm{L}-\mathrm{OHP} / \mathrm{GA}$ cells was $12.54 \mu \mathrm{mol} / \mathrm{l}$ and the RI was 1.06 . The results demonstrated that the LoVo/L-OHP cells were resistant to L-OHP, and that GA inhibited this resistance.
Whether the established L-OHP-resistant cells and sensitive cells were able to maintain their characteristics was also assessed. LoVo/L-OHP cells were cultured in complete RPMI-1640 medium without L-OHP for 15 days, following which the $\mathrm{IC}_{50}$ for the $\mathrm{LoVo} / \mathrm{L}-\mathrm{OHP}$ cells was $46.43 \mu \mathrm{mol} / 1$, the RI was 3.92 and resistance remained at $86.29 \%$ viable cells. Subsequent to storage in liquid nitrogen $\left(-196^{\circ} \mathrm{C}\right)$ for 2 months, recovered LoVo/L-OHP cells were able to grow and proliferate. The $\mathrm{IC}_{50}$ for the recovered $\mathrm{LoVo} / \mathrm{L}-\mathrm{OHP}$ cells was $47.97 \mu \mathrm{mol} / 1$ and the RI was 4.05 , indicating that the established $\mathrm{LoVo} / \mathrm{L}-\mathrm{OHP}$ cells were able to maintain resistance. Regarding the LoVo/L-OHP/GA cells, following culture incomplete RPMI-1640 medium without GA for 15 days, the $\mathrm{IC}_{50}$ was $12.93 \mu \mathrm{mol} / \mathrm{l}$ and the RI was 1.09 . The resistance was $27.85 \%$ of all viable LoVo/L-OHP cells, which was higher compared with the first established cells ( $23.0 \%$ viable cells). The LoVo/L-OHP/GA cells recovered from liquid nitrogen were also able to grow and proliferate. $\mathrm{The} \mathrm{IC}_{50}$ for the recovered cells was $13.92 \mu \mathrm{mol} / \mathrm{l}$ and the RI was 1.18 , suggesting that GA was able to reverse L-OHP resistance, and that the L-OHP-sensitive cells had been successfully established.

Morphological changes of LoVo/L-OHP and LoVo/L-OHP/GA cells. The morphological changes of the established cells were then observed through inverted light microscopy (magnification, $\mathrm{x} 800$ ). As demonstrated in Fig. 2, the parent LoVo cells were adherent, flat and polygonal, with numerous cell junctions. LoVo/L-OHP-resistant cells were rounder and bigger, and the nuclei were clearer. The LoVo/L-OHP/GA cells exhibited a similar appearance to the recovered LoVo cells.

$G A$ reverses the anti-apoptosis ability of the LoVo/L-OHP cells. LoVo, LoVo/L-OHP and LoVo/L-OHP/GA cells were treated with $20 \mu \mathrm{mol} / 1 \mathrm{~L}-\mathrm{OHP}$ for $6 \mathrm{~h}$, following which the apoptosis rates were determined by flow cytometry. As indicated in Fig. 3, the apoptosis induced by L-OHP in the LoVo and $\mathrm{LoVo} / \mathrm{L}-\mathrm{OHP} / \mathrm{GA}$ cells was $66.02 \pm 5.30$ and $54.21 \pm 5.52 \%$, respectively. It is noteworthy that L-OHP only induced minimal levels of apoptosis in the LoVo/L-OHP-resistant cells, with only $4.56 \pm 1.70 \%$ apoptosis. A comparison of apoptosis rates revealed that the rate was decreased in the $\mathrm{LoVo} / \mathrm{L}-\mathrm{OHP}$ cells compared with the LoVo and LoVo/L-OHP/GA cells $(\mathrm{P}<0.01)$, and that the apoptosis rate in the $\mathrm{LoVo} / \mathrm{L}-\mathrm{OHP} / \mathrm{GA}$ cells was decreased compared with that in the LoVo cells $(\mathrm{P}<0.05)$. The results suggested that the anti-apoptosis ability of the 

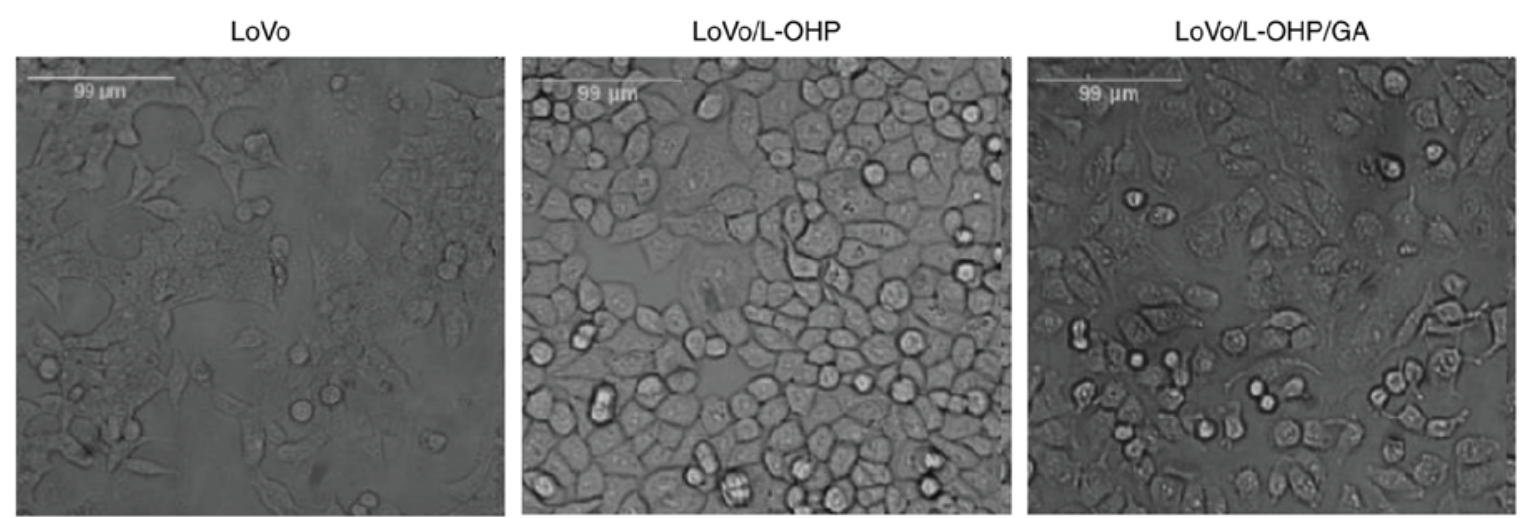

Figure 2. Morphological changes of LoVo/L-OHP and LoVo/L-OHP/GA cells captured using inverted microscopy. L-OHP, oxaliplatin; GA, gambogic acid.
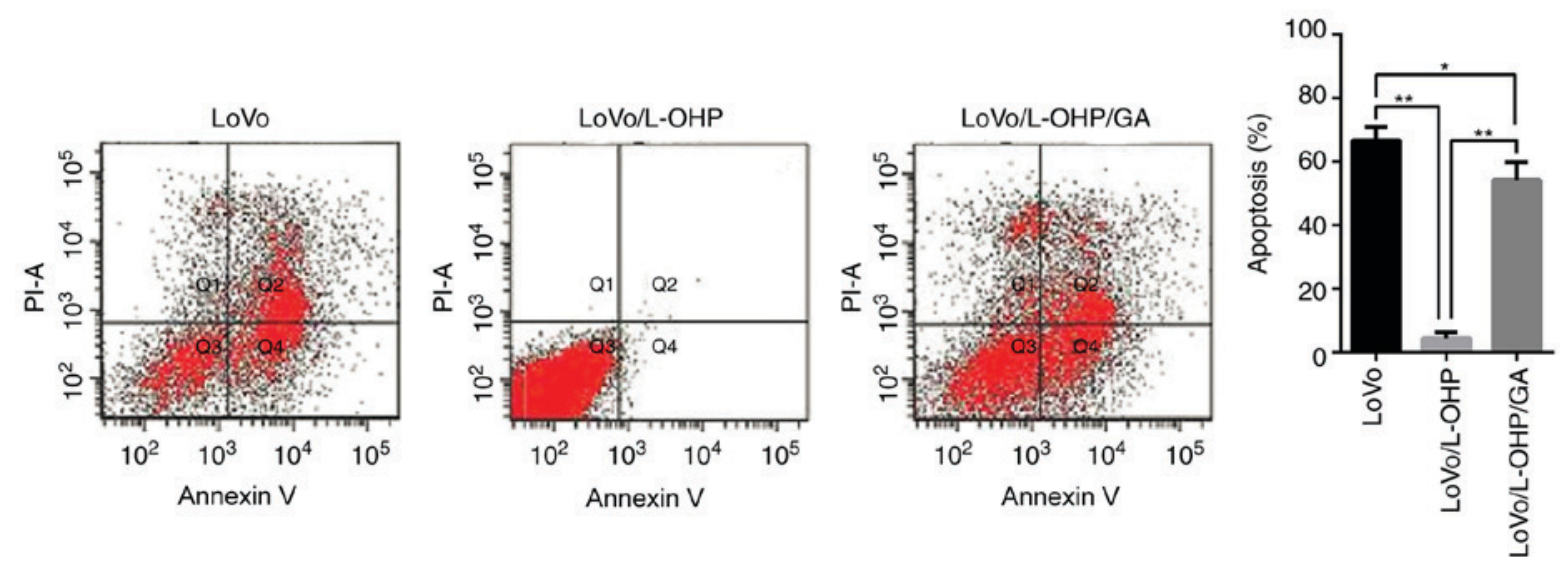

Figure 3. Apoptosis rates of LoVo, LoVo/L-OHP and LoVo/L-OHP/GA cells in the presence of L-OHP ( $20 \mu \mathrm{mol} / 1$ for $6 \mathrm{~h})$, ${ }^{*} \mathrm{P}<0.05$ and ${ }^{* *} \mathrm{P}<0.01$. L-OHP, oxaliplatin; GA, gambogic acid; PI, propidium iodide.

LOVO/L-OHP cells was increased compared with the LoVo and $\mathrm{LoVo} / \mathrm{L}-\mathrm{OHP} / \mathrm{GA}$ cells, and that GA reversed these effects.

GA attenuates invasion in the LoVo/L-OHP cells. LoVo, $\mathrm{LoVo} / \mathrm{L}-\mathrm{OHP}$ and $\mathrm{LoVo} / \mathrm{L}-\mathrm{OHP} / \mathrm{GA}$ cells were treated with $2 \mu \mathrm{mol} / 1 \mathrm{~L}-\mathrm{OHP}$ for $24 \mathrm{~h}$, following which the levels of invasion were determined in Transwell assays. The numbers of invasive LoVo, LoVo/L-OHP and LoVo/L-OHP/GA cells was $21 \pm 0.12$, $46 \pm 0.15$ and $17 \pm 0.09$, respectively. As demonstrated in Fig. 4, a comparison of the numbers of invading cells revealed that the LoVo/L-OHP cells yielded an increased number of invasive cells compared with the LoVo and LoVo/L-OHP/GA cells $(\mathrm{P}<0.01)$. Subsequent to treatment with $\mathrm{L}-\mathrm{OHP}$, the invasive ability of the LoVo/L-OHP cells was increased compared with that of the LoVo and $\mathrm{LoVo} / \mathrm{L}-\mathrm{OHP} / \mathrm{GA}$ cells, suggesting that the rates of invasion in $\mathrm{LoVo} / \mathrm{L}-\mathrm{OHP}$-resistant cells increased, and that GA was able to reverse and attenuate the invasion.

Determination of intracellular Pt content. To explore the potential mechanisms by which GA reversed resistance to L-OHP, the intracellular content of Pt was detected. As demonstrated in Fig. 5A, it was identified that intracellular $\mathrm{Pt}$ accumulated as the concentration of L-OHP increased, indicating that L-OHP entered into cells in a dose-dependent manner. Following $4 \mathrm{~h}$ treatment with different concentrations $(0,0.5,1,2$ or $4 \mu \mathrm{mol} / \mathrm{l})$ of L-OHP, the Pt content in LoVo and $\mathrm{LoVo} / \mathrm{L}-\mathrm{OHP} / \mathrm{GA}$ cells was increased compared with the $\mathrm{LoVo} / \mathrm{L}-\mathrm{OHP}$ cells $(\mathrm{P}<0.05)$. Intracellular $\mathrm{Pt}$ content was highest in the LoVo cells, followed by LoVo/L-OHP/GA cells, and then lowest in the LoVo/L-OHP cells.

The Pt content of cells then was detected following treatment with $2 \mu \mathrm{mol} / 1 \mathrm{~L}-\mathrm{OHP}$ for different times (1,4, 12 and $24 \mathrm{~h}$ ). It was identified that intracellular Pt accumulated as treatment time intervals increased, indicating a time-dependent effect. There was no difference between the LoVo, LoVo/L-OHP and $\mathrm{LoVo} / \mathrm{L}-\mathrm{OHP} / \mathrm{GA}$ cells at 1 and $4 \mathrm{~h}(\mathrm{P}>0.05)$. At 12 and $24 \mathrm{~h}$, the $\mathrm{Pt}$ content in the LoVo and $\mathrm{LoVo} / \mathrm{L}-\mathrm{OHP} / \mathrm{GA}$ cells was increased compared with the LoVo/L-OHP cells $(\mathrm{P}<0.05)$. $\mathrm{Pt}$ content in the LoVo cells was increased compared with the LoVo/L-OHP/GA cells at 12 and $24 \mathrm{~h}(\mathrm{P}<0.05$; Fig. 5B).

hCTR1, ATP7A and ATP7B protein levels. In order to determine whether the changes in intracellular Pt were associated with copper transporters, the protein expressions of hCTR1, ATP7A and ATP7B in LoVo, LoVo/L-OHP and LoVo/ L-OHP/GA cells were examined. As demonstrated in Fig. 6, hCTR1 protein levels were decreased in the $\mathrm{LoVo} / \mathrm{L}-\mathrm{OHP}$ cells compared with in the LoVo and LoVo/L-OHP/GA cells $(\mathrm{P}<0.01)$, and decreased in the $\mathrm{LoVo} / \mathrm{L}-\mathrm{OHP} / \mathrm{GA}$ cells compared with the LoVo cells $(\mathrm{P}<0.01)$. The protein levels of ATP7A and ATP7B were increased in the LoVo/L-OHP cells compared with the LoVo and LoVo/L-OHP/GA cells 

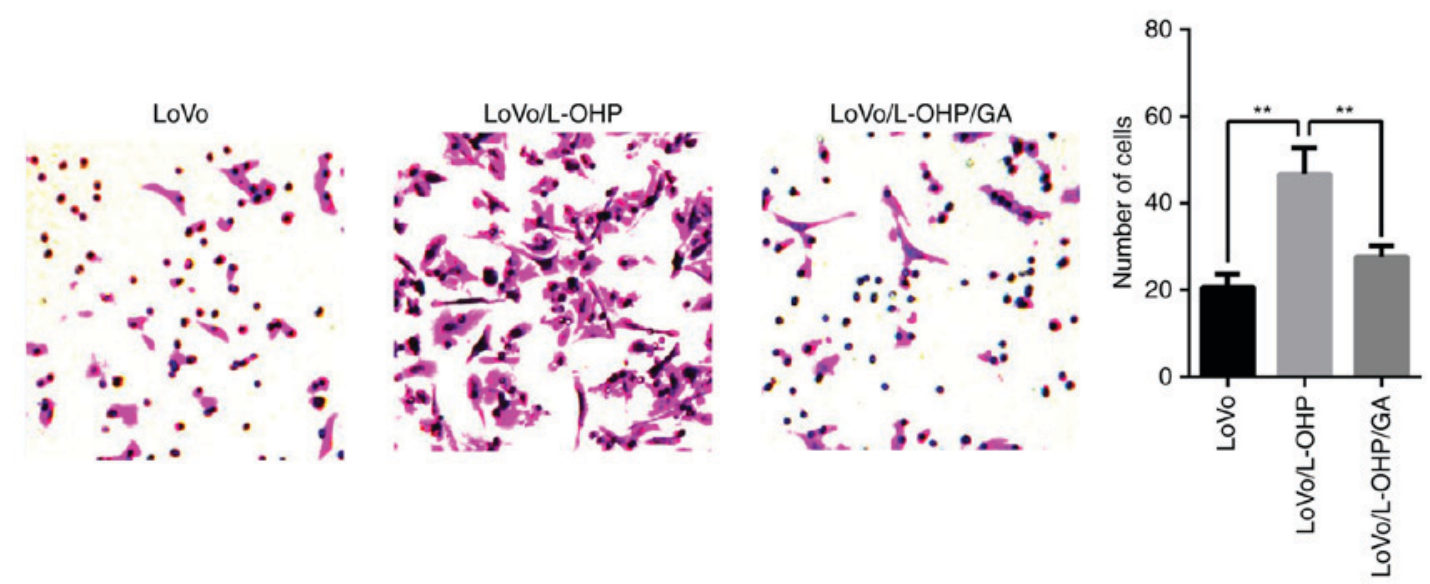

Figure 4. Invasion by LoVo, LoVo/L-OHP and LoVo/L-OHP/GA cells in the presence of L-OHP ( $2 \mu \mathrm{mol} / \mathrm{l}$ for $24 \mathrm{~h})$, visualised using haematoxylin staining by light microscopy (magnification, $\mathrm{x} 400$ ). Numbers of cells represent the invasive abilities of LoVo, LoVo/L-OHP and LoVo/L-OHP/GA cells. ${ }^{* *} \mathrm{P}<0.01$. L-OHP, oxaliplatin; GA, gambogic acid.
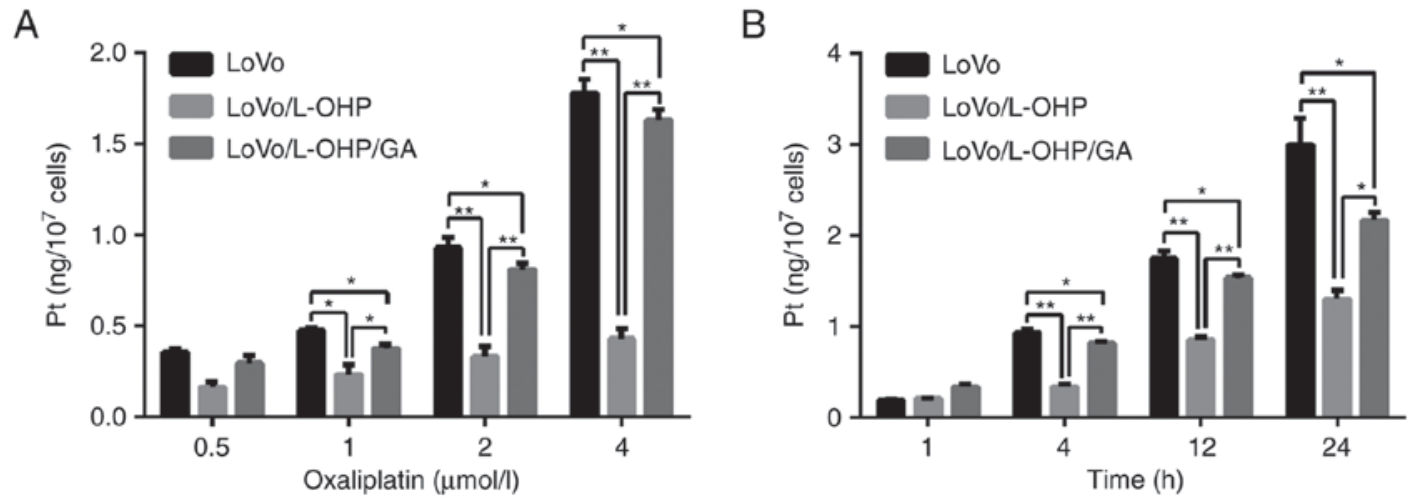

Figure 5. Intracellular Pt levels of LoVo, LoVo/L-OHP and LoVo/L-OHP/GA cells in the presence of L-OHP. (A) Different concentrations (0.5, 1, 2 and $4 \mu \mathrm{mol}$ ) of L-OHP for $4 \mathrm{~h}$. (B) A total of $2 \mu \mathrm{mol} / 1 \mathrm{~L}-\mathrm{OHP}$ at different time intervals $(1,4,12$ and $24 \mathrm{~h})$. ${ }^{*} \mathrm{P}<0.05$ and ${ }^{* *} \mathrm{P}<0.01$. Pt, platinum; L-OHP, oxaliplatin; GA, gambogic acid.
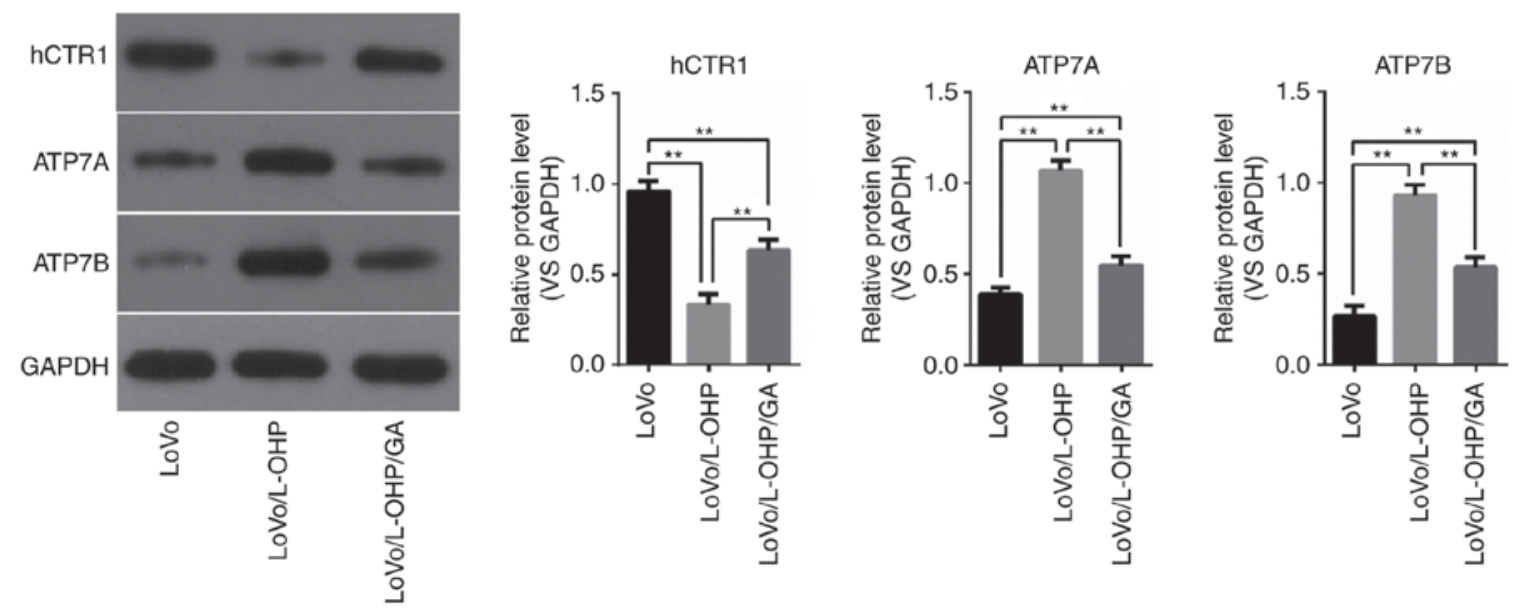

Figure 6. Western blotting reveals protein levels of hCTR1, ATP7A and ATP7B in LoVo, LoVo/L-OHP and LoVo/L-OHP/GA cells. ** P $<0.01$. GA, gambogic acid; L-OHP, oxaliplatin; hCTR1, human copper transporter 1; ATP7A, copper-transporting p-type adenosine triphosphatases 1; ATP7B, copper-transporting p-type adenosine triphosphatases 2.

$(\mathrm{P}<0.01)$, with levels being increased in the LoVo/L-OHP/GA cells compared with the LoVo cells $(\mathrm{P}<0.01)$. These results suggest that downregulated hCTP1 and upregulated ATP7A and ATP7B were associated with L-OHP resistance, and that GA reversed the resistance by increasing the levels of hCTR1 and decreasing ATP7A and ATP7B levels. 


\section{Discussion}

Resistance to L-OHP remains one of the major obstacles in chemotherapy for CRC, and it is essential to identify novel drugs to overcome or reverse L-OHP resistance. GA is a traditional Chinese medicine with multi-target anticancer effects, including the inhibition of proliferation (20), induction of apoptosis (21), cell cycle arrest (22), and inhibition of angiogenesis (23), invasion and metastasis (24). GA was also identified to exhibit inhibitory effects on resistance to anticancer drugs in CRC (12), breast (13), ovarian (14), gastric (15) and human epithelial cancer (16).

Therefore, in the present study, the possibility of using GA to reverse L-OHP resistance in CRC cells was evaluated. It was identified that the $\mathrm{LoVo} / \mathrm{L}-\mathrm{OHP}$ cells were resistant to $\mathrm{L}-\mathrm{OHP}$, and that GA reversed this resistance. Compared with the parent LoVo cells, the anti-apoptosis and invasive abilities of resistant LOVO/L-OHP cells were improved, and GA was able to reverse these effects. Intracellular Pt content was highest in the LoVo cells, followed by the LoVo/L-OHP/GA cells, and then lowest in the LoVo/L-OHP cells. Decreased hCTP1 levels and increased ATP7A and ATP7B levels were associated with L-OHP resistance, and GA reversed this resistance by increasing hCTR1 and decreasing ATP7A and ATP7B levels. These results indicated that GA exhibited the ability to reverse L-OHP resistance in CRC cells, which was associated with an increase in intracellular Pt content and a regulation of the protein expression levels of copper transporters.

The cytotoxic effects of Pt drugs are directly associated with intracellular Pt content, and the majority of resistant cells exhibit decreased intracellular accumulation of these drugs (25). Adequate intracellular accumulation of Pt drugs is essential to exert their anticancer effects (7). Intracellular Pt content was directly associated with the content of L-OHP in cells, while intracellular L-OHP content is positively associated to the sensitivity of cells to L-OHP (7). In the present study, intracellular Pt content was determined by ICP-MS, and it was identified that intracellular L-OHP content increased in a doseand time-dependent manner. Intracellular L-OHP content was highest in the LoVo cells, followed by the LoVo/L-OHP/GA cells, and then lowest in the LoVo/L-OHP cells, suggesting that parent LoVo cells were relatively sensitive to L-OHP, that LoVo/L-OHP cells were resistant to L-OHP, and that GA was able to reverse this resistance.

The process of cellular import and export of Pt drugs is primarily mediated by copper transporters (8). hCTR1, ATP7A and ATP7B are key copper transporters involved in intracellular $\mathrm{Pt}$ accumulation (9). hCTR1 regulates the influx of Pt drugs, while ATP7A and ATP7B regulate the efflux of these drugs (9). Previous studies have indicated that copper transporters not only regulate the influx and efflux of Pt drugs, but also affect cell cytotoxic sensitivity to $\mathrm{Pt}$ drugs: Ishida et al (26) identified that the downregulation of hCTR1 resulted in the reduced accumulation of cisplatin and increased cisplatin resistance. Song et al (27) also identified that the upregulation of hCTR1 enhanced the accumulation of oxaliplatin and carboplatin in small-cell lung cancer cells. Low expression of hCTR1 was determined to be associated with poor prognosis in patients with non-small cell lung cancer (NSCLC) and ovarian cancer treated with Pt-based chemotherapy $(28,29)$. hCTR1 is a potential biomarker for intracellular Pt accumulation and Pt drug resistance. ATP7A serves an important role in $\mathrm{Pt}$ resistance by transporting $\mathrm{Pt}$ drugs out of cells (30). The overexpression of ATP7A was associated with $\mathrm{Pt}$ resistance in oesophageal squamous cell cancer (31), NSCLC (32), CRC (33) and ovarian cancer (34). Overexpressed ATP7A was also identified to predict a poor prognosis in patients with NSCLC receiving Pt-based chemotherapy (32). Similar to ATP7A, ATP7B facilitates the efflux of Pt drugs, and also affects resistance to Pt drugs (35). ATP7B silencing resulted in improved cisplatin sensitivity in cisplatin-resistant ovarian cells (36). The overexpression of ATP7B was associated with Pt resistance in patients with $\mathrm{CRC}$, and predicted poor prognosis in patients following oxaliplatin-based chemotherapy (37). In the present study, it was identified that hCTR1 protein levels were decreased in resistant $\mathrm{LoVo} / \mathrm{L}-\mathrm{OHP}$ cells compared with parent LoVo and L-OHP-sensitive LoVo/L-OHP/GA cells, while ATP7A and ATP7B protein levels were increased in resistant cells, indicating that downregulated hCTP1 and upregulated ATP7A and ATP7B were associated with L-OHP resistance, and that GA may reverse this resistance by increasing hCTR1 and decreasing ATP7A and ATP7B levels.

Overall, the results of the present study demonstrated that GA exhibits the potential ability to reverse L-OHP resistance in CRC cells. The potential reversal mechanism may involve an increase in intracellular Pt content and hCTR1 levels, and a decrease in ATP7A and ATP7B levels, making it a potential treatment agent for L-OHP resistance.

\section{Acknowledgements}

Not applicable.

\section{Funding}

The present study was supported by grants from National Natural Science Foundation of China (grant no. 81272556), Guangdong Planned Project of Science and Technology (grant nos. 2014A020212614 and 2017A020215009), Guangdong Science and Research Project of Traditional Chinese Medicine Bureau (grant no. 20152039) and Guangzhou Planned Project of Science and Technology (grant no. 2014Y2-00137).

\section{Availability of data and materials}

The datasets used and/or analysed in the present study are available from the corresponding author on reasonable request.

\section{Authors' contributions}

QW, WL, JC, JW and CW designed the study. JW and CW wrote the manuscript. TZ, DH, FW and $\mathrm{FH}$ performed the experiments. WC, PY and SZ collected and analysed the data. All authors read and approved the final manuscript.

\section{Ethics approval and consent to participate}

Not applicable. 


\section{Consent for publication}

Not applicable.

\section{Competing interests}

The authors declare that they have no competing interests.

\section{References}

1. Torre LA, Bray F, Siegel RL, Ferlay J, Lortet-Tieulent J and Jemal A: Global cancer statistics, 2012. CA Cancer J Clin 65: 87-108, 2015.

2. Chen W, Zheng R, Baade PD, Zhang S, Zeng H, Bray F, Jemal A, Yu XQ and He J: Cancer statistics in China, 2015. CA Cancer J Clin 66: 115-132, 2016

3. André T, Iveson T, Labianca R, Meyerhardt JA, Souglakos I, Yoshino T, Paul J, Sobrero A, Taieb J, Shields AF, et al: The IDEA (International Duration Evaluation of Adjuvant Chemotherapy) collaboration: Prospective combined analysis of phase III trials investigating duration of adjuvant therapy with the FOLFOX (FOLFOX4 or modified FOLFOX6) or XELOX (3 versus 6 months) regimen for patients with stage III colon cancer: Trial design and current status. Curr Colorectal Cancer Rep 9: 261-269, 2013.

4. Guo J, Zhu C, Yang K, Li J, Du N, Zong M, Zhou J and He J: Poly $(\mathrm{C})$-binding protein 1 mediates drug resistance in colorectal cancer. Oncotarget 8: 13312-13319, 2017.

5. Alcindor T and Beauger N: Oxaliplatin: A review in the era of molecularly targeted therapy. Cur Oncol 18: 18-25, 2011.

6. Martinez-Balibrea E, Martínez-Cardús A, Ginés A, Ruiz de Porras V, Moutinho C, Layos L, Manzano JL, Bugés C, Bystrup S, Esteller M and Abad A: Tumor-related molecular mechanisms of oxaliplatin resistance. Mol Cancer Ther 14: 1767-1776, 2015.

7. Hall MD, Okabe M, Shen DW, Liang XJ and Gottesman MM: The role of cellular accumulation in determining sensitivity to platinum-based chemotherapy. Annu Rev Pharmacol Toxicol 48 495-535, 2008

8. Harrach S and Ciarimboli G: Role of transporters in the distribution of platinum-based drugs. Front Pharmacol 6: 85, 2015.

9. Rabik CA, Maryon EB, Kasza K, Shafer JT, Bartnik CM and Dolan ME: Role of copper transporters in resistance to platinating agents. Cancer Chemother Pharmacol 64: 133-142, 2009.

10. Zhang Y, Zhang Q, Fan Z, Sun J, Liu X, Cheng L, Li A and $\mathrm{Xu}$ J: A Chinese herbal formula, Chang-Wei-Qin, synergistically enhances antitumor effect of oxaliplatin. Pathol Oncol Res 21: 389-397, 2015.

11. Qi Q, You Q, Gu H, Zhao L, Liu W, Lu N and Guo Q: Studies on the toxicity of gambogic acid in rats. J Ethnopharmacol 3: 433-438, 2008

12. Wen C, Huang L, Chen J, Lin M, Li W, Lu B, Rutnam ZJ, Iwamoto A, Wang Z, Yang X and Liu H: Gambogic acid inhibits growth, induces apoptosis, and overcomes drug resistance in human colorectal cancer cells. Int J Oncol 47: 1663-1671, 2015.

13. Wang S, Wang L, Chen M and Wang Y: Gambogic acid sensitizes resistant breast cancer cells to doxorubicin through inhibiting P-glycoprotein and suppressing survivin expression. Chem Biol Interact 235: 76-84, 2015

14. Wang $\mathrm{J}$ and Yuan Z: Gambogic acid sensitizes ovarian cancer cells to doxorubicin through ROS-mediated apoptosis. Cell Biochem Biophys 67: 199-206, 2013.

15. Wang T, Wei J, Qian X, Ding Y, Yu L and Liu B: Gambogic acid, a potent inhibitor of survivin, reverses docetaxel resistance in gastric cancer cells. Cancer Lett 262: 214-222, 2008.

16. Wang X, Deng R, Lu Y, Xu Q, Yan M, Ye D and Chen W: Gambogic acid as a non-competitive inhibitor of ATP-binding cassette transporter $\mathrm{B} 1$ reverses the multidrug resistance of human epithelial cancers by promoting ATP-binding cassette transporter B1 protein degradation. Basic Clin Pharmacol Toxicol 112: 25-33, 2013.

17. Martinez-Cardús A, Martinez-Balibrea E, Bandrés E, Malumbres R, Ginés A, Manzano JL, Taron M, Garcia-Foncillas J and Abad A: Pharmacogenomic approach for the identification of novel determinants of acquired resistance to oxaliplatin in colorectal cancer. Mol Cancer Ther 8: 194-202, 2009.
18. Plasencia C, Martínez-Balibrea E, Martinez-Cardús A, Quinn DI, Abad A and Neamati N: Expression analysis of genes involved in oxaliplatin response and development of oxaliplatinresistant HT29 colon cancer cells. Int J Oncol 29: 225-235, 2006.

19. Nguyen TT, Ostergaard J, Stürup S and Gammelgaard B Determination of platinum drug release and liposome stability in human plasma by CE-ICP-MS. Int J Pharm 449: 95-102, 2013.

20. Xu J, Zhou M, Ouyang J, Wang J, Zhang Q, Xu Y, Xu Y, Zhang Q, $\mathrm{Xu} \mathrm{X}$ and Zeng $\mathrm{H}$ : Gambogic acid induces mitochondria-dependent apoptosis by modulation of Bcl-2 and Bax in mantle cell lymphoma JeKo-1 cells. Chin J Cancer Res 2: 183-191, 2013

21. Duan D, Zhang B, Yao J, Liu Y, Sun J, Ge C, Peng S and Fang J: Gambogic acid induces apoptosis in hepatocellular carcinoma SMMC-7721 cells by targeting cytosolic thioredoxin reductase. Free RadicBiol Med 69: 15-25, 2014

22. Zhao W, Zhou SF, Zhang ZP, Xu GP, Li XB and Yan JL: Gambogic acid inhibits the growth of osteosarcoma cells in vitro by inducing apoptosis and cell cycle arrest. Oncol Rep 25: 1289-1295, 2011.

23. Lu N, Hui H, Yang H, Zhao K, Chen Y, You QD and Guo QL: Gambogic acid inhibits angiogenesis through inhibiting PHD2-VHL-HIF-1 $\alpha$ pathway. Eur J Pharm Sci 49: 220-226, 2013.

24. Qi Q, Lu N, Li C, Zhao J, Liu W, You Q and Guo Q: Involvement of RECK in gambogic acid induced anti-invasive effect in A549 human lung carcinoma cells. Mol Carcinog 54 (Suppl 1): E13-E25, 2015.

25. Howell SB, Safaei R, Larson CA and Sailor MJ: Copper transporters and the cellular pharmacology of the platinum-containing cancer drugs. Mol Pharmacol 77: 887-894, 2010.

26. Ishida S, Lee J, Thiele DJ and Herskowitz I: Uptake of the anticancer drug cisplatin mediated by the copper transporter Ctrl in yeast and mammals. Proc Natl Acad Sci USA 99: 14298-14302, 2002.

27. Song IS, Savaraj N, Siddik ZH, Liu P, Wei Y, Wu CJ and Kuo MT: Role of human copper transporter Ctr1 in the transport of platinum-based antitumor agents in cisplatin-sensitive and cisplatin-resistant cells. Mol Cancer Ther 3: 1543-1549, 2004

28. Chen HH, Yan JJ, Chen WC, Kuo MT, Lai YH, Lai WW, Liu HS and Su WC: Predictive and prognostic value of human copper transporter 1 (hCtr1) in patients with stage III non-small-cell lung cancer receiving first-line platinum-based doublet chemotherapy. Lung Cancer 75: 228-234, 2012.

29. Ishida S, McCormick F, Smith-McCune K and Hanahan D: Enhancing tumor-specific uptake of the anticancer drug cisplatin with a copper chelator. Cancer Cell 17: 574-583, 2010.

30. Chisholm CL, Wang H, Wong AH, Vazquez-Ortiz G, Chen W, $\mathrm{Xu} \mathrm{X}$ and Deng CX: Ammonium tetrathiomolybdate treatment targets the coppertransporter ATP7A and enhances sensitivity of breast cancer tocisplatin. Oncotarget 51: 84439-84452, 2016.

31. Li ZH, Zheng R, Chen JT, Jia J and Qiu M: The role of copper transporter ATP7A in platinum-resistance of esophageal squamous cell cancer (ESCC). J Cancer 7: 2085-2092, 2016.

32. Li ZH, Qiu MZ, Zeng ZL, Luo HY, Wu WJ, Wang F, Wang ZQ, Zhang DS, Li YH and Xu RH: Copper-transporting P-type adenosine triphosphatase (ATP7A) is associated with platinum-resistance in non-small cell lung cancer (NSCLC). J Transl Med 10: 21, 2012

33. Kitada N, Takara K, Minegaki T, Itoh C, Tsujimoto M, Sakaeda T and Yokoyama T: Factors affecting sensitivity to antitumor platinum derivatives of human colorectal tumor cell lines. Cancer Chemother Pharmacol 62: 577-584, 2008.

34. Mangala LS, Zuzel V, Schmandt R, Leshane ES, Halder JB, Armaiz-Pena GN, Spannuth WA, Tanaka T, Shahzad MM, Lin YG, et al: Therapeutic targeting of ATP7B in ovarian carcinoma. Clin Cancer Res 15: 3770-3780, 2009.

35. Nakagawa T, Inoue Y, Kodama H, Yamazaki H, Kawai K, Suemizu H, Masuda R, Iwazaki M, Yamada S, Ueyama Y, et al: Expression of copper-transporting P-type adenosine triphosphatase (ATP7B) correlates with cisplatin resistance in human non-small cell lung cancer xenografts. Oncol Rep 20: 265-270, 2008.

36. Leonhardt K, Gebhardt R, Mössner J, Lutsenko S and Huster D: Functional interactions of $\mathrm{Cu}$-ATPase ATP7B with cisplatin and the role of ATP7B in the resistance of cells to the drug. J Biol Chem 284: 7793-802, 2009

37. Martinez-Balibrea E, Martínez-Cardús A, Musulén E, Ginés A, Manzano JL, Aranda E, Plasencia C, Neamati N and Abad A: Increasedlevels of copper efflux transporter ATP7B are associated withpoor outcome in colorectal cancer patients receiving oxaliplatin-based chemotherapy. Int J Cancer 124: 2905-2910, 2009.

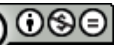

This work is licensed under a Creative Commons Attribution-NonCommercial-NoDerivatives 4.0 International (CC BY-NC-ND 4.0) License. 